\title{
A Short History of Neuroradiology and Interventional Neurology in the World and in Turkey
}

\author{
Dünya'da ve Türkiye'de Nöroloji ve Girişimsel Nörolojinin Kısa Tarihçesi
}

Keywords: History, neuroradiology, interventional neurology

Anahtar Kelimeler: Tarihçe, nöroradyoloji, girişimsel nöroloji

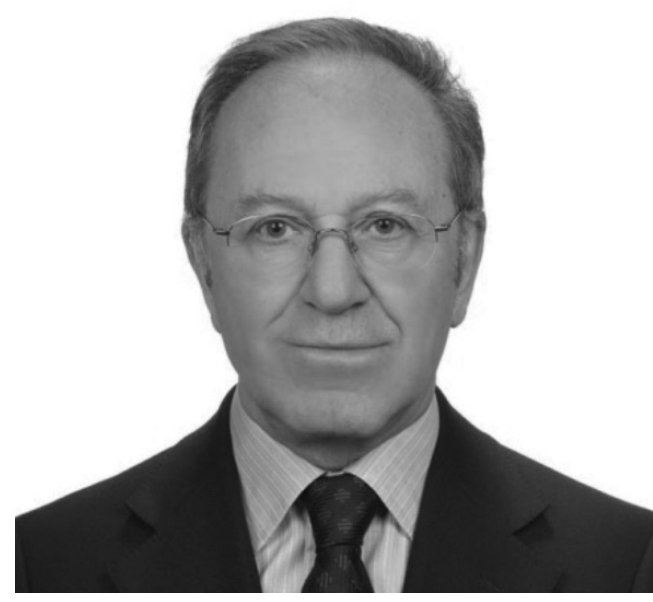

A Short History of Neuroradiology and Interventional Neurology in the World and in Turkey

The history of diagnostic neuroradiology begins with the invention of X-ray, and then its application as craniography in the very early $20^{\text {th }}$ century. A famous neurosurgeon, Dandy, was the first to perform pneumoencephalography in 1918. The technique depended on drainage of spinal fluid and an injection of the same amount of air in about a total of $50 \mathrm{~mL}$ volume through a lumbar puncture in a patient in the sitting position, and craniograms were obtained that showed the ventricular system and the subarachnoid spaces. A version of this technique is ventriculogram, where contrast material, either air or iodinated, was injected through a cannula inserted in one of the lateral ventricles. Siccard introduced myelography through the lumbar route in 1923. Egas Moniz, a neurologist from Portugal, was the first to perform cerebral angiography in 1927 by injecting iodinated contrast material into the surgically exposed cervical carotid artery. One of the first six patients died due to the toxic effects of the iodinated contrast agent. The technique was abandoned for a few years, and then restarted as less toxic iodinated contrast materials were developed. Diagnostic angiography gained more importance after the Seldinger technique was introduced in 1952, which enabled catheterization of both carotid and vertebral arteries by a single puncture of one femoral artery. As years passed, less toxic iodinated contrast agents, less traumatic and thinner catheterization materials, and better X-ray equipment were developed. All these techniques showed brain or spinal cord indirectly, through filling of the ventricles, subarachnoid spaces or vessels by contrast materials. As can be observed from the above information the pioneers of neuroradiology in the world were mainly neurologists and neurosurgeons.

Then came the era of visualizing neural or other soft tissues directly by the invention of computed tomography (CT) in 1972 by an English electronic engineer, Godfrey Hounsfield. This revolutionary radiologic invention was followed by magnetic resonance imaging (MRI) that was developed by Lauterburg and Damadian in the early 1980s. MRI can roughly be defined as a more sophisticated and refined form of CT. Interest of radiologists

Address for Correspondence/Yazışma Adresi: Mehmet Reha Tolun MD, Istanbul Aydin University Hospital, Istanbul, Turkey Phone: +90 5323113373 E-mail: r_tolun@yahoo.com ORCID: orcid.org/0000-0002-4416-3122 Received/Geliş Tarihi: 11.11.2019 Accepted/Kabul Tarihi: 15.11.2019

${ }^{\circ}$ Copyright 2019 by Turkish Neurological Society Turkish Journal of Neurology published by Galenos Publishing House. 
in neuroradiologic examinations grew after the invention of 'remote systems' such as CT and MRI!

In the late 1950s and early 1960s, a few neurosurgeons and neurologists in Turkey began performing pneumoencephalograpy, ventriculography, myelography or direct puncture carotid angiography.

The first Turkish modern neuroradiologist, who began performing catheter-based 4 vessel angiography, was Dr. Gençay Gürsoy from Istanbul University Neurology Department who was trained by a famous European neuroradiologist Amundsen from Norway. Dr. Gürsoy was trained in Norway through 19681970 and 1972-1974. In the same years, Dr. Okay Sarıbaş and Dr. Mesude Duyguner from Hacettepe University Neurology Department in Ankara were the other pioneers of modern neuroradiology in Turkey. After Dr. Gürsoy left for Norway for the second time in 1972, Dr. Reha Tolun from the same Neurology Department of Istanbul University Istanbul Medical Faculty began performing neuroradiologic examinations. Dr. Tolun was then trained by Dr. Jean Jacques Merland in Paris University Hospital, Lariboisiére, between 1979-1980 in spinal and therapeutic angiography. Dr. Tolun was the pioneer of therapeutic neuroangiography in Turkey. Dr. Tolun and his neurologist colleagues Dr. Sara Bahar, Dr. Halil Atilla İdrisoğlu, Dr. Rezzan Tunçay, and Dr. Oğuzhan Çoban ran the Diagnostic and Therapeutic Neuroradiology Section of the Neurology Department of Istanbul Medical Faculty through 1982-1994. This section of Neuroradiology, run only by neurologists, was a reference center in Turkey. Dr. Gürsoy rejoined the department in 1989 after 7 years of exile from the university for political reasons.

Another neurologist, Dr. Gazi Özdemir, a classmate of Dr. Tolun, was performing direct puncture carotid angiographies in the early 1970s, and catheter-based cerebral angiographies after 1978 together with his neurology colleagues from Osmangazi Univesity Medical Faculty in Eskisehir. Dr. Gazi Özdemir had a long fight against radiologists who thought that the field belonged only to them. Radiologists brought this fight to court rooms, but finally, after years of struggle, Dr. Gazi Özdemir won this fight, and neuroangiograhy was then legally open to neurologists. His son, Dr. Özcan Özdemir, was to take over the mission as an interventional neurologist in the 2010s. Dr. Semih Giray from Adana, and Dr. Erdem Gürkaş from Ankara, were the other interventional neurologists at those times.

Dr. Cıvan Işlak, a radiologist from Istanbul University Cerrahpasa Medical Faculty, was trained by Dr. Luc Piccard in therapeutic neuroangiography in France. Dr. Işlak, together with another radiologist, Işıl Saatçi from Ankara Hacettepe University, were the pioneers of interventional neuroradiology in Turkey. They began their hometown practices in the early 1990s. Dr. Naci Koçer joined Dr. Işlak in Istanbul, and Dr. Saruhan Çekirge joined Dr. Işıl Saatçi soon after in Ankara.

In the late 1980s, a long debate was running in Istanbul Medical Faculty, whether Neuroradiology should belong to the Department of Neurology or to the Department of Radiology. Neurologists claimed that this department belonged to them because they had the expertise, and that they were the practioners. Radiologists were saying that the field naturally belonged to them. Finally, a commission formed by the faculty members from other specialties of the university decided that the solution to the problem was to declare Neuroradiology as an independent department, just as Neurology or Radiology. In 1989, the Department of Neuroradiology was founded in Istanbul Medical Faculty, and Dr. Reha Tolun from Neurology and Dr. Cahit Babuna from Radiology were assigned as faculty. This was not easy to ingest for radiologists nationwide, and finally they put all their political power to solve the problem to their wish, and they succeeded. This department was abolished by the High Educational Council 'Yükseköğretim Kurulu', and Neuroradiology became a section of the Radiology Department of Istanbul Medical Faculty. The old equipment in Neurology's Neuroradiology section finally collapsed, and new equipment was installed in the Radiology Department, where Dr. Özenç Minareci from the Radiology Department began heading the Neuroradiology Section. As can be seen, neuroradiology was taken over by radiologists in Turkey. But, this was not the end of the story!

Dr. Tolun, after several years, resigned from Istanbul University, and restarted practicing therapeutic neuroangiography in Florence Nightingale Hospital in 2002, mainly in the fields of intraarterial thrombolysis, and carotid artery stenting. Dr. Yakup Krespi joined him in 2005. Dr. Krespi organized the first comprehensive stroke center of Turkey in that hospital. Dr. Tolun, together with his colleagues Dr. Yakup Krespi and Dr. Bahar Aksay Koyuncu, served on a 24-7 basis for endovascular thrombolysis/thrombectomy of patients with acute ischemic stroke beginning in Florence Nightingale Hospital, and then continuing in Memorial Hospital in Istanbul through 2002-2016.

In 2008, Dr. Yakup Krespi, Dr. Özcan Özdemir, Dr. Semih Giray, and Dr. Erdem Gürkaş, and my classmate Gazi Özdemir asked me to form a working group of Interventional Neurology within the Turkish National Society of Neurology. The Society founded "The Working Group of Neuroradiology", and Dr. Tolun was assigned as the moderator in 2009. The group's name was changed to "The Working Group of Interventional Neurology" in 2011. Dr. Özcan Özdemir was elected as the next moderator in December 2016.

In the early 2000s, Dr. Gomez and Dr. Adnan Qureshi were the pioneers of interventional neurology in the United States of America (USA). Now there are more than 100 interventional neurologists in the USA. Together with certain neurosurgeons, most of the interventional neuroradiologic procedures are now performed by physicians from neuroscience origin in the USA.

Dr. Adnan Qureshi attended the 45th National Congress of Neurology in 2009 in Antalya as an invited speaker of the Working Group of Interventional Neurology. Dr. Qureshi then invited Dr. Tolun as an invited speaker to the First International Congress of Interventional Neurology held in 2011 in Minneapolis, and then to the two successive yearly congresses. In 2014, a Euro-Asian Working Group of Interventional Neurology, the name coined by me, held a meeting in the $50^{\text {th }}$ National Congress of Neurology in Antalya. Dr. Adnan Qureshi, Dr. Qaisar Shah, Dr. Osman Şamil Kozak from the USA, Dr. Shakir Husain from India, Dr. Marc Ribo from Spain, Dr. Mikail Mazighi from France, and Dr. Adam Kobayashi from Poland participated in this congress.

The main theme of the 52nd National Congress of Neurology held in Antalya in November 2016 was "Vascular Neurology and Interventional Neurology", led by the Working Group 
of Interventional Neurology. Three successive plenary session conferences were given by Dr. Reha Tolun, Dr. Tudor Jovin, and Dr. Mayank Goyal, in addition to the other activities of The Working Group of Interventional Neurology in this Congress.

The Turkish National Society of Neurology's Working Groups of Interventional Neurology, Cerebrovascular Diseases, and Neuro-Critical Care prepared a document of "Vascular Neurology Subspecialty," and this document was presented to the Ministry of Health in 2013. The subspecialty training duration was 3 years. Training for the first year would be in clinical stroke and neurocritical care, for the second year mainly diagnostic neuroradiology, and the third year was dedicated to interventional neurology. We knew that such an accomplishment would not be easy due to inherent opposition from the radiology community. Therefore, we decided to give a "Certificate of Interventional Neuroangiography" to trainees who would complete two years of full training in competent centers.

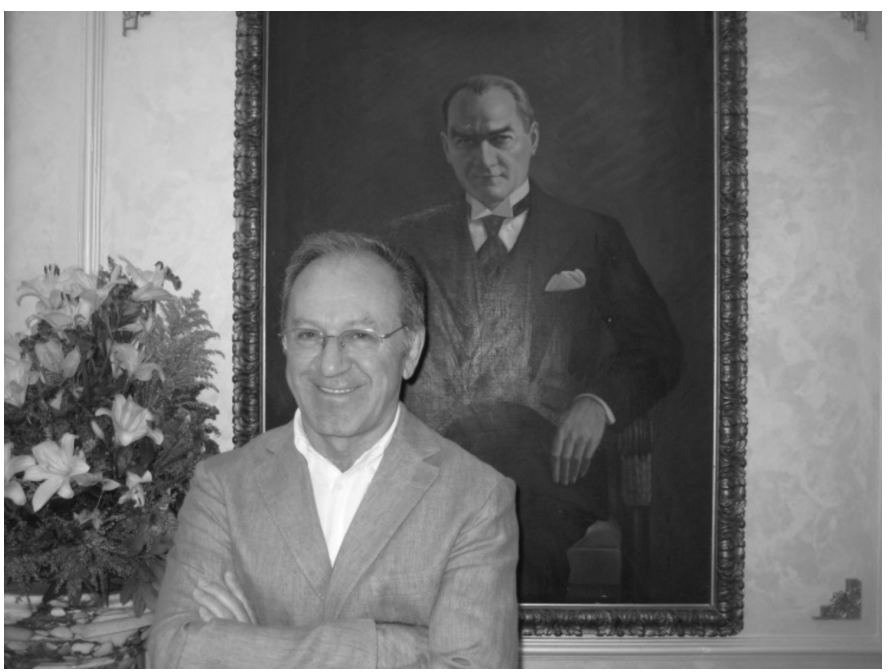

Reha Tolun in front of Atatürk's portrait
Dr. Özcan Özdemir from Eskisehir, Dr. Semih Giray from Gaziantep, Dr. Erdem Gürkaş from Ankara, and Dr. Zulfikar Arlier from Adana have been practicing interventional neurology since 2010 in their departments of neuroangiography. Together with my team in Istanbul, these are the 5 centers in Turkey that are now capable of training young neurologists to become certified as neurointerventionists. The number of interventional neurologists nowadays in Turkey has reached 30, and 20 more are currently under training.

One other achievement was the joint recognition of already trained and experienced vascular neurologists by the Turkish National Society of Neurology and the Turkish National Society of Cerebrovascular Diseases.

As for interventional neurology in other European countries, there are probably very few interventional neurologists. The number maybe about 10, from some countries such as Spain, France, and Poland. There are probably even fewer neurosurgeons in Europe practicing endovascular neurosurgery.

It seems reasonable to us that, similar to cardiologists who medically take care of their patients, and also perform their interventional cardiac procedures, neurologists and neurosurgeons may perform the neurointerventional procedures of their patients.

We believe that the number of endovascular neurointerventionists, either from neurology or neurosurgery origins, will rise in the near future in Europe, and in the world.

We should admit that, neurointerventional procedures carry a significant risk of morbidity and mortality. So, neurointerventionists, either from radiology, neurology or neurosurgery origins, should have completed formal, highquality training, for a sufficient duration. This training may best be given in academic centers with joint programs of Neurology, Neurosurgery, and Radiology departments.

Reha Tolun, May 2019 